Vol.8, Issue 5, pp.1-14, May 2020

Published by ECRTD- UK

Print ISSN: ISSN 2054-6351: Online ISSN: ISSN 2054-636X

\title{
CURRICULUM EVALUATION: A COMPARATIVE STUDY OF A 4-YEAR B.Ed. REGULAR AND A 2-YEAR DIPLOMA SANDWICH STUDENTS' RESULTS IN MUSIC, MOVEMENT AND DRAMA
}

\author{
${ }^{1}$ Hans Kweku Anderson, ${ }^{2}$ Abraham Kwadwo Okrah, ${ }^{3}$ Cyril Ababio Titty \\ $1 \& 3$ (University of Education, Winneba, Department of Basic Education, P. O. Box 25, \\ Winneba Ghana, West Africa.) \\ ${ }^{2}$ (University of Ghana, Legon, Department of Teacher Education, School of \\ Education and Leadership, P. O. Box LG 25, Accra Ghana, West Africa.)
}

\begin{abstract}
Both the Bachelor of Education (B.Ed.) and Diploma students at the University of Education, Winneba, Ghana, use the same content as prescribed in the Academic Bulletin but both are admitted on two different entry requirements with different duration accordingly. Sections of society speculate about varied performances of both categories of students without any empirical evidence. The purpose of the study was to ascertain how well the students have been prepared in terms of content assimilation and their relative performance. Using a purposive sampling technique, both regular and sandwich Music, Movement and Drama Level 200 students of the Department of Early Childhood Education of the University from 2008 to 2012 were selected for the study. Test results of the respondents from 2008 to 2012 which served as the data were analysed, after ethical issues were resolved, using descriptive and inferential statistics. The results showed that both regular and sandwich students performed creditably well within the range of the years under review. It was, however, established that there was a statistically significant difference between the achievement of the B.Ed. regular and Diploma sandwich students from 2008 to 2012 academic years. On the basis of the findings, it was recommended that the mode of delivery of the sandwich programme be reconsidered such that there will be a bridge of the gap between the regular and the sandwich programmes in terms of performance.
\end{abstract}

KEYWORDS: Curriculum, evaluation, sandwich, diploma, music, movement, drama, Bachelor of Education, regular.

\section{INTRODUCTION}

Tanner and Tanner (1995) opine that curriculum is a "plan or programme of all experiences which the learner encounters under the direction of a school' (p.158). Thus, a curriculum is deliberately planned for instruction in schools where supervision is done by the school authorities to ensure effective transmission of the planned experiences for learners. 
Wheeler (1967) identifies five stages of curriculum; namely: Aims, goals and objectives, selection of learning experiences, selection of content, organization and integration of experiences and then evaluation. Curriculum process entails curriculum planning, curriculum implementation and curriculum evaluation. This study assesses the evaluation aspect of the Music, Movement and Drama course taught to Level 200 students of the Departments of the University of Education, Winneba.

Evaluation, according to Patton (2008), involves the systematic collection of information about the activities, characteristics, and outcomes of programmes, personnel, and products for use by specific people to reduce uncertainties, improve effectiveness, and make decisions with regard to what those programmes, personnel or products are doing and emphasizes (1) a systematic collection of information about (2) a broad range of topics (3) for use by specific people (4) for a variety of purpose.

Thus, the evaluator should have a set goal(s) and ascertain whether or not the set goal (s) is/are being realized. To do this effectively, the evaluator gathers information on the specific item to be evaluated and after value judgement has been made, uses the outcome for decision making.

Tamakloe, Amedahe and Atta (1996) say evaluation involves gathering information on a person, programme or a process and trying to form judgments about the effectiveness of what is evaluated. For them, before the process of evaluation, there is the need for the evaluator to gather data on whatever is to be evaluated, march it with some given criterion before judgment about its effectiveness or otherwise could be determined.

Stufflebeam (2000) adds that evaluation is a study designed and conducted to assist some audience to assess an object's merit or worth. Thus, the idea of finding out the worth of what is being evaluated is reiterated by Stufflebeam. In the classroom, Tamakloe et al (1996) opine that the teaching/learning process cannot be complete without measuring and evaluating learning outcomes. They identify the following as tools for evaluation: observations, surveys, interviews, questionnaires, checklists and tests. Tyler (2013), cited in Flinders and Thornton (eds.), reiterates that one aspect of evaluation focuses on the extent to which students are developing in the desired way. So, learning experiences are marched with examination achievements.

Taras (2008) postulates that there is summative and formative forms of evaluation; and that as the formative one is ongoing as the programme of study progresses, the summative one is done at the end of a programme. Tamakloe et al (1996) add that summative evaluation can be done internally by a teacher who is directly involved in the execution of an instructional programme.

The programme to be evaluated is Music, Movement and Drama, a course offered by the Level 200 students of the Department of Early Childhood Care and Development 
of the University of Education, Winneba. Scriven (1967), as confirmed in Ketabi and Ketabi (2014), assets that evaluation could be done on students at a particular level and for a particular subject, and then decision made about the students' subsequent behaviour in order to come out with the overall evaluation of an entire programme. Also, Oliva (1992) cautions that there should be process evaluation which is aimed at providing periodic feedback while the curriculum is being implemented for decision making. Thus, having taught the course since the first batch of students in the said department till today as the students have reached level 200, there is the need for an evaluation of some kind to be conducted to ascertain the impact of the programme on the students. More so, with the introduction of the Sandwich course in the department whose students also take the course within half the number of weeks used by the regular students, a study of such nature is very important. This is because, students of both programmes of the course are as follows: WASSCE/SSSCE holders. They must have six (6) WASSCE/SSSCE passes including three core subjects: English Language, Mathematics, and Science/Integrated Science. They are expected to employ the skills gained from studying the course in teaching. Badders (2000) says in such cases there should be an authentic assessment which is an examination of students' performance and understanding on significant tasks that have relevance to the students' life inside and outside of the classroom.

The entry requirements for the Bachelor of Education (B.Ed.) programme are that the candidate must at least have grade 'C6' in any three Electives with a total aggregate of 24 or better. Mature applicants (i) must be at least 25 years by September of the academic year one wants to enrol (ii) must hold Teachers' Certificate 'A' or (iii) WASSCE/SSSCE Certificate of Professional Training from a recognized institution (iv) must pass the UEW Entrance Examination.

The entry requirement for the Sandwich (Diploma) programme is as follows: (i) A Distinction or Credit in Certificate in Pre- School Education from an accredited institution or (ii) Five SHS/GCE passes including English Language and Mathematics or (iii) Teachers' Certificate 'A' (iv) Applicants with higher qualifications can apply.

French (2007) writes that a good education in the early years with practical activities offers foundations for effective learning. Cobbold (2011) advises that courses offered at the pre- service period of the early childhood teacher should address, among other things, how the teacher is going to carry out instruction in the school. To buttress Cobbold's assertion, Berliner and Biddle, as cited in Dixon, Yssil, McConnell and Hardin (2014), have added that teachers in general should have some level of professionalism to be able to teach effectively. The Music, Movement and Drama course has been planned to equip the teacher trainees with skills and knowledge that would enable them to handle the course efficiently taking cognisance of the psychomotor, cognitive and affective development of the pre-school child (Asemanyi \& Wunku, 2007, Yakubu, 2000). 
The course content covers the following areas:

i. Music-Singing

ii. Listening

iii. Musical instruments

iv. Creative movement and dance

v. Physical exercises to music

vi. Ability to act scenes from stories told

vii. Acting with others in a group

viii. Exploring ways of dressing up and dancing

ix. Drama, Acting, Play

x. Setting up a stage

xi. Culture, dance and play

xii. Histories and stories of various people

xiii. Expressions and modes of communication

Ruland (2015) posits that discussion ensures the active participation of students in the teaching/learning process. Tamakloe et al (1996) say the project method affords treat opportunity for students, especially the low achievers, to participate in practical learning situations which give them the much needed intrinsic motivation. According to them, the Lecture method provides information on themes which are not available or easily accessible to students. In addition, Velazqez and Assar (2009) and Natoli (2011) argue that in a lecture, demonstration materials such as relia, diagrams, charts, etc, are used by teachers to facilitate teaching and learning. In cognisance of the above descriptions of methods of instruction, and given the practical nature of the course, the instructional strategies used for the two sets of students were: Discussion, Projects, Lecture and Demonstration.

Even though the same methods of instruction are used to teach the course to the two categories of students, there is the need to ascertain how well the students are prepared in terms of content assimilation as they are all going to teach at the same level (Owu-Ewie, 2006). Scriven (1967) writes that such evaluation helps in comparing two programmes of the same sort to determine their appropriateness.

\section{Purpose of the study}

Tamakloe et al (1996) intimate that one function of a test is to serve as an instrument in gauging educational characteristics. The purpose of the study, therefore, was to identify differences in performance of the B.Ed and Sandwich students taking the Music, Movement and Drama course in UEW, Winneba, so as to offer suggestions for programme modification (Abdullatif, 2013).

\section{Research questions}

The following research questions guided the study: 
1. How well did B.Ed. Regular and Diploma Sandwich students of UEW, Winneba, perform on Music, Movement and Drama course?

2. Which mode of entry (Regular and Sandwich) is in the higher performance group than the other in the Music, Movement and Drama course?

\section{Hypothesis}

$\boldsymbol{H}_{\boldsymbol{O}}=$ There will be no significant difference in the academic achievement of the B.Ed Regular and Diploma Sandwich students of UEW, Winneba in the Music, Movement and Drama course.

$\boldsymbol{H}_{\boldsymbol{I}}=$ There will be a significant difference in the academic achievement of the B Ed Regular and Diploma Sandwich students of UEW, Winneba in the Music, Movement and Drama course.

\section{METHODOLOGY}

The study is inclined towards the quantitative paradigm in which descriptive as well as inferential statistics coupled with sampled t-test were used in analysing the data. It involved the collection and analysis of data to ascertain the differences that exist between the B.Ed and Sandwich students of UEW, Winneba, in their performances with reference to the Music, Movement and Drama course. Effective strategies for the modification of the course for the benefit of both groups of students taking it were also explored. Scriven (1967) says analysis of students' performance on their final tests assists with the determination of exact location of short comings associated with the programme.

\section{Study population}

According to Agyedu, Donkor, and Obeng, (2011), population in research is the complete set of individuals (subjects), objects or events with common observable features for which a researcher is interested in studying. The population of the study comprised all regular and sandwich Music, Movement and Drama Level 200 students of the Department of Early Childhood Education of UEW, Winneba, from 2008 to 2012. Data in Table 1 show the yearly distribution of the students that took the course since the Sandwich programme was introduced in the Department studied. 
Print ISSN: ISSN 2054-6351: Online ISSN: ISSN 2054-636X

Table 1: Distribution of Study Population on Yearly Bases

\begin{tabular}{llc}
\hline Year & Programme & Number of students \\
\hline 2008 & Regular & 126 \\
2008 & Sandwich & 109 \\
2009 & Regular & 353 \\
2009 & Sandwich & 121 \\
2010 & Regular & 125 \\
2010 & Sandwich & 197 \\
2011 & Regular & 129 \\
2011 & Sandwich & 190 \\
2012 & Regular & 148 \\
2012 & Sandwich & 489 \\
\hline Total & Sandwich \& Regular \\
\hline
\end{tabular}

\section{Sampling}

Maheshwati (2011) intimates that sampling is the idea of selecting some of the elements in a population for the purpose of studying their properties to gain information about the whole population. The purposive sampling technique was used to select subjects for this study for the reason that they had taken the course and written examination at the end of their respective semesters. Also, since the study sought to evaluate the two programmes, all students who have taken the course since the introduction of the Sandwich programme in the Department were covered. They were in all 1,987 (See Table1).

\section{Instrumentation}

The research instrument was teacher made test which consisted of forty per cent (40\%) Continuous Assessment marks and sixty per cent (60\%) end of Semester Examination marks. Tamakloe et al (1996) write that test scores can provide data for research in the classroom. The continuous assessment covered one quiz written and submitted on individual basis and a project on miming which was performed on group basis.

\section{Validity and Reliability}

The End of Semester Examination questions were all validated by the Heads of Department of the said Department over the years ever since the first batch of students took the course. This exercise, according to Lankshear and Knobel (2004), would help ensure that the tests would truly measure what they were purported to measure and also to ensure their consistency over time (Joppe, 2000).

\section{Procedure for data collection}

The data used for the study comprised a compilation of all the certified results on Music, Movement and Drama by the Faculty Board of the Faculty of Educational Studies of UEW, Winneba, over the period studied. Official permission was sought from the Registrar of the Institution in question for use of the results. 


\section{Data Analysis}

The data from the respondents were transposed from their raw state to the University's approved grading system for undergraduate students (UEW, 2008, p. 1619) before using them for the analysis. The collected data were analysed using SPSS Version 23.0. The analytic approaches adopted in analysing the data included descriptive and inferential statistics. The research questions were analysed descriptively by computing frequencies, percentages, mean and standard deviation on the data set. Measures of shape, such as skewness and kurtosis, also aided the analysis of the research questions. The hypothesis was, however, analysed inferentially. Thus independence sampled $t$-test was used to analyse the hypothesis.

\section{RESULTS AND DISCUSSION}

To determine how well B.Ed Regular and Diploma Sandwich students of UEW, Winneba, performed on Music, Movement and Drama course, the students' grades were subjected to the descriptive statistics. The results of the analysis for 2008/2009 academic year are indicated in Table 2.

Table 2: Summary of 2008/2009 Academic Performance for the Two Cohorts

\begin{tabular}{lrrrrr}
\hline & \multicolumn{2}{c}{ B. Ed. Regular } & & \multicolumn{2}{c}{ Diploma Sandwich } \\
\cline { 2 - 3 } \cline { 5 - 6 } Grade & Frequency & Percentage & & Frequency & Percentage \\
\hline $80-100 \rightarrow{ }^{\prime}$ 'A' & 22 & 17.5 & & 10 & 9.2 \\
$75-79 \rightarrow$ 'B+', & 28 & 22.2 & & 15 & 13.8 \\
$70-74 \rightarrow$ 'B' & 14 & 11.1 & & 16 & 14.6 \\
$65-69 \rightarrow{ }^{\prime} \mathrm{C}+{ }^{\prime}$, & 22 & 17.5 & & 19 & 17.4 \\
$60-64 \rightarrow$ 'C' & 11 & 8.7 & & 15 & 13.8 \\
$55-59 \rightarrow$ 'D+' & 20 & 15.8 & & 18 & 16.5 \\
$50-54 \rightarrow$ 'D' & 2 & 1.6 & & 9 & 8.3 \\
$00-49 \rightarrow$ 'E' & 7 & 5.6 & & 7 & 6.4 \\
\hline Total & $\mathbf{1 2 6}$ & $\mathbf{1 0 0}$ & & $\mathbf{1 0 9}$ & $\mathbf{1 0 0}$ \\
Mean $($ Std.) & $\mathbf{5 . 4 0}(\mathbf{2 . 0})$ & & & $\mathbf{4 . 7 2}(\mathbf{2 . 0})$ & \\
Skewness & $\mathbf{- 0 . 4 6 0}$ & & & $\mathbf{- 0 . 9 3 0}$ & \\
Kurtosis & $\mathbf{- 0 . 7 8 5}$ & & & $\mathbf{- 0 . 9 3 9}$ & \\
\hline
\end{tabular}

A closer examination of the results presented in Table 2 indicate that for the regular students, $94.4 \%$ (119) passed the course but 5.6\% (7) failed whiles for the sandwich students $93.6 \%$ (102) passed the course but 6.4\% (7) filed. Examination mean scores of 5.40 (2.0) and 4.72 (2.0) were recorded for regular and sandwich students respectively. In order to check if the distribution of the examinations scores were normally distributed, an inspection of the measures of the shapes was carried out. The analysis indicated that the skewness and kurtosis test gave -0.460 and -0.785 
respectively for regular students while -0.930 and -0.939 were the results recorded for sandwich students.

The result in the case of the 2009/2010 academic year indicates that 347 (98.3\%) of the regular students passed while 6 representing $1.7 \%$ failed and 113 representing $93.4 \%$ of the sandwich students passed while $6.6 \%(n=8)$ failed. The detailed findings on the 2009/2010 academic year are presented in Table 3 as follows:

Table 3: Summary of 2009/2010 Academic Performance for the Two Cohorts

\begin{tabular}{|c|c|c|c|c|}
\hline & \multicolumn{2}{|c|}{ B. Ed. Regular } & \multicolumn{2}{|c|}{ Diploma Sandwich } \\
\hline Grade & Frequency & Percentage & Frequency & Percentage \\
\hline $80-100 \rightarrow{ }^{\prime} A$ ' & 50 & 14.2 & 13 & 10.7 \\
\hline $75-79 \rightarrow{ }^{'} \mathrm{~B}+$ ' & 62 & 17.6 & 21 & 17.4 \\
\hline $70-74 \rightarrow{ }^{'} \mathrm{~B}$ ' & 47 & 13.3 & 18 & 14.9 \\
\hline $65-69 \rightarrow{ }^{\prime} \mathrm{C}+$ ' & 62 & 17.6 & 22 & 18.2 \\
\hline $60-64 \rightarrow{ }^{'} C^{\prime}$ & 41 & 11.6 & 12 & 9.9 \\
\hline $55-59 \rightarrow{ }^{'} \mathrm{D}+$ ' & 45 & 12.7 & 17 & 14.0 \\
\hline $50-54 \rightarrow{ }^{'} \mathrm{D}$ ' & 40 & 11.3 & 10 & 8.3 \\
\hline $00-49 \rightarrow{ }^{'} \mathrm{E}$ ' & 6 & 1.7 & 8 & 6.6 \\
\hline Total & 353 & 100 & 121 & 100 \\
\hline Mean (Std.) & $5.12(2.0)$ & & $4.95(2.1)$ & \\
\hline Skewness & -0.186 & & -0.264 & \\
\hline Kurtosis & -1.105 & & -0.971 & \\
\hline
\end{tabular}

Following from the forgoing frequency and percentage results presented from Table 3 , a mean and standard deviation scores were calculated. The findings reveal that a mean and standard deviation scores of $5.12($ Std. $=2.0)$ and $4.95($ Std. $=2.1)$ were recorded for both regular and sandwich students respectively. To check if the distribution scores are normal, the measures of shape (kurtosis and skewness) were examined. The analysis shows that a skewness and kurtosis test result of -0.186 and 1.105 respectively were recorded for regular students while a similar test reveals a similar result of -0.264 and -0.971 were respectively recorded for the sandwich students.

Academic achievement among the 2010/2011 academic year of both the sandwich and regular students was also analysed and the finding is presented in Table 4. 
Print ISSN: ISSN 2054-6351: Online ISSN: ISSN 2054-636X

Table 4: Summary of 2010/2011 Academic Performance for the Two Cohorts

\begin{tabular}{|c|c|c|c|c|}
\hline \multirow[b]{2}{*}{ Grade } & \multicolumn{2}{|c|}{ B. Ed. Regular } & \multicolumn{2}{|c|}{ Diploma Sandwich } \\
\hline & Frequency & Percentage & Frequency & Percentage \\
\hline $80-100 \rightarrow{ }^{\prime} A$ ' & 32 & 25.6 & 5 & 2.5 \\
\hline $75-79 \rightarrow$ 'B+' & 34 & 27.2 & 17 & 8.6 \\
\hline $70-74 \rightarrow{ }^{'} \mathrm{~B}$ ' & 31 & 24.8 & 27 & 13.7 \\
\hline $65-69 \rightarrow{ }^{\prime} \mathrm{C}+$ ' & 14 & 11.2 & 32 & 16.2 \\
\hline $60-64 \rightarrow{ }^{'} \mathrm{C}$ ' & 7 & 5.6 & 44 & 22.3 \\
\hline $55-59 \rightarrow{ }^{\prime} \mathrm{D}+$ ' & 7 & 5.6 & 25 & 12.7 \\
\hline $50-54 \rightarrow{ }^{'} \mathrm{D}$ ' & 0 & 0 & 25 & 12.7 \\
\hline $00-49 \rightarrow{ }^{'} \mathrm{E} '$ & 0 & 0 & 22 & 11.2 \\
\hline Total & 125 & 100 & 197 & 100 \\
\hline Mean (Std.) & $6.39(1.4)$ & & $4.08(1.9)$ & \\
\hline Skewness & -0.777 & & 0.301 & \\
\hline Kurtosis & -0.480 & & -0.832 & \\
\hline
\end{tabular}

Academic performance in the case of 2010/2011 academic year as presented in Table 4 reveals that $100 \%(n=125)$ of the regular students passed their examination and this attracted a mean and standard deviation of 6.39 and 1.4 respectively. On the other hand, data presented on sandwich students' performance during the same academic year show that $175(88.8 \%)$ of them passed while 22 representing $11.2 \%$ failed. This result cumulated into a mean and standard deviation scores of 4.08 and 1.9 respectively. The measures of shape results revealed a skewness and kurtosis of 1.777 and -0.480 respectively for regular students whiles 0.301 and -0.832 were reported for the sandwich students.

The analysis of the results for the 2011/2012 academic year for both regular and sandwich students is presented in Table 5. The study's findings show that $100 \%(n=$ 129) of the regular students passed the Music, Movement and Drama course whereas 3 representing $1.6 \%$ of the sandwich students failed and $98.4 \%(n=187)$ passed the course. The results on the skewness and kurtosis test indicate that -0.487 and -0.134 respectively were the skewness and kurtosis results for regular students while 0.294 and -0.873 were the skewness and kurtosis results generated for sandwich students. 
British Journal of Education

Vol.8, Issue 5, pp.1-14, May 2020

Published by $E C R T D-U K$

Print ISSN: ISSN 2054-6351: Online ISSN: ISSN 2054-636X

Table 5: Summary of 2011/2012 Academic Performance for the Two Cohorts

\begin{tabular}{|c|c|c|c|c|}
\hline \multirow[b]{2}{*}{ Grade } & \multicolumn{2}{|c|}{ B. Ed. Regular } & \multicolumn{2}{|c|}{ Diploma Sandwich } \\
\hline & Frequency & Percentage & Frequency & Percentage \\
\hline $80-100 \rightarrow{ }^{\prime} A$ ' & 17 & 13.2 & 5 & 2.6 \\
\hline $75-79 \rightarrow$ 'B+' & 38 & 29.5 & 18 & 9.5 \\
\hline $70-74 \rightarrow{ }^{'} \mathrm{~B}$ ' & 30 & 23.3 & 23 & 12.1 \\
\hline $65-69 \rightarrow$ 'C+' & 30 & 23.3 & 30 & 15.8 \\
\hline $60-64 \rightarrow{ }^{'} \mathrm{C}$ ' & 9 & 7.0 & 42 & 22.1 \\
\hline $55-59 \rightarrow{ }^{\prime} \mathrm{D}+$ ' & 4 & 3.1 & 25 & 13.2 \\
\hline $50-54 \rightarrow{ }^{'} \mathrm{D}$ ' & 1 & 0.8 & 44 & 23.2 \\
\hline $00-49 \rightarrow{ }^{'} \mathrm{E}$ ' & 0 & 0 & 3 & 1.6 \\
\hline Total & 129 & 100 & 190 & 100 \\
\hline Mean (Std.) & $6.06(1.3)$ & & $4.15(1.8)$ & \\
\hline Skewness & -0.487 & & 0.294 & \\
\hline Kurtosis & -0.134 & & -0.873 & \\
\hline
\end{tabular}

Finally, the summary of the academic performance of the 2012/2013 regular and sandwich students is presented in Table 6. The study's results point out that all 148 regular students representing $100 \%$ passed the examination on Music, Movement and Drama course whereas $99.8 \%$ representing 488 sandwich students passed the course and 1 representing $0.2 \%$ failed the course. The means of the academic performance for the regular students during the 2012/2013 academic year were 5.94 and 1.4 respectively whiles those of the sandwich students were 4.30 and 1.7 respectively. The skewness and kurtosis test gave -0.620 and 0.038 for regular students while 0.367 and -0.876 were the results generated for sandwich students.

Table 6: Summary of 2012/2013 Academic Performance for the Two Cohorts

\begin{tabular}{|c|c|c|c|c|}
\hline \multirow[b]{2}{*}{ Grade } & \multicolumn{2}{|c|}{ B. Ed. Regular } & \multicolumn{2}{|c|}{ Diploma Sandwich } \\
\hline & Frequency & Percentage & Frequency & Percentage \\
\hline $80-100 \rightarrow{ }^{\prime} A^{\prime}$ & 16 & 10.8 & 20 & 4.1 \\
\hline $75-79 \rightarrow{ }^{'} \mathrm{~B}+$ ' & 44 & 29.7 & 42 & 8.6 \\
\hline $70-74 \rightarrow{ }^{'} \mathrm{~B}$ ' & 36 & 24.3 & 72 & 14.7 \\
\hline $65-69 \rightarrow{ }^{'} \mathrm{C}+$ ' & 30 & 20.3 & 77 & 15.7 \\
\hline $60-64 \rightarrow{ }^{'} \mathrm{C}$ ' & 14 & 9.5 & 83 & 17.0 \\
\hline $55-59 \rightarrow{ }^{\prime} \mathrm{D}+$ & 5 & 3.4 & 113 & 23.1 \\
\hline $50-54 \rightarrow{ }^{'} \mathrm{D}$ ' & 3 & 2.0 & 81 & 16.6 \\
\hline $00-49 \rightarrow{ }^{'} \mathrm{E}$ ' & 0 & 0 & 1 & 0.2 \\
\hline Total & 148 & 100 & 489 & 100 \\
\hline Mean (Std.) & $5.94(1.4)$ & & $4.30(1.7)$ & \\
\hline Skewness & -0.620 & & 0.367 & \\
\hline Kurtosis & 0.038 & & -0.876 & \\
\hline
\end{tabular}




\section{Hypothesis}

$\boldsymbol{H}_{\boldsymbol{o}}=$ There will be no significant difference in the academic achievement of the B Ed Regular and Diploma Sandwich students of UEW, Winneba in the Music, Movement and Drama course.

In order to examine whether the difference between the two examinations mean scores of the students from the two mode of entry was significant, the researchers employed independent-samples t-test. The result of the t-test is presented in Table 7.

Table 7: Summary of $t$-test 2008 - 2012 Academic Year

\begin{tabular}{clcccccc}
\hline Year & Group & $\boldsymbol{N}$ & Mean & Std. & Df & $\boldsymbol{t}$ & sig. \\
\hline \multirow{2}{*}{$2008-2012$} & Regular & 881 & 5.62 & 1.82 & \multirow{2}{*}{1985} & \multirow{2}{*}{15.37} & \multirow{2}{*}{0.00} \\
& Sandwich & 1106 & 4.35 & 1.85 & & & \\
\hline
\end{tabular}

The examination mean score on the academic achievement of the regular students $[M$ $=5.62$, Std.$=1.82]$ during the $2008-2012$ academic year was higher than that of the sandwich students $[M=4.35, S t d .=1.85]$. The observed difference in the academic achievement of the two modes of entry groups, as established by independent-samples t-test was statistically significant $[t(1985)=15.37, p=0.00, d=0.69]$. The magnitude of the difference represents an intermediate effect size (0.69) based on Cohen's rule of thumb. The rule of thumb for effect size is as follows: Cohen's $d=$ 0.20 or less is considered small, Cohen's $d=0.50$ is medium, and Cohen's $d=0.80$ is considered large (Cohen, 1969). The effect size expressed as a percentage is $69 \%(d=$ 0.69) and can consequently be reported that the variance between the two modes of entry was evidently wide. It can therefore be inferred from the basic and intermediate statistical analysis presented that regular students are consistent and in the high performance group that cuts across various academic years than the sandwich students.

\section{CONCLUSIONS}

It can be concluded from the analysis that students from each of the two modes of entry (regular and sandwich) did perform well during the year under review. From the findings again, it was clear that there was a statistically significant difference between the achievement of regular and sandwich students from 2008 - 2012 academic years. Consequently, one can conclude that the regular students outperformed their counterparts from the sandwich section. Sandwich section may, therefore, not be a guarantee for better academic achievement on the Music, Movement and Drama course in the University of Education, Winneba. The findings of this study were corroborated in literature. Okwara (1997) compared academic achievement of regular and post N.C.E sandwich students of University of Port-Harcourt. The results from the study revealed that there were significant differences in few individual courses commonly offered by them in favour of the regular students. 
However, the results obtained in this study did not support the assertion that either sandwich students generally perform better than regular students or there was no significant difference in their performance as reported in some literature. For instance, Oku (2008) compared academic achievement of sandwich and regular masters students of the University of Port Harcourt. Purposive sampling technique was used to sample 288 sandwich and 485 regular masters students from three departments in the faculty of education. Results from Oku's study revealed a no significant differences between the two groups of students in most of the courses commonly offered by them in the three departments. Another finding which is in concordance with that of Oku is that of Funke (1992). Funke found that full-time (regular) and part-time (sandwich) students in a degree programme in the University of Lagos do not differ significantly in terms of academic achievement.

\section{Recommendations}

Both cohorts of students obtain the same certificate and they turn out to be teachers who implement the same curriculum or syllabus and who teach the same calibre of students. It is, therefore, recommended that the mode of delivery of the sandwich programme be reconsidered such that there will be a bridge of the gap between the regular and the sandwich programmes in terms of performance be filled up.

\section{References}

Abdullatif, M. (2013). Fraud risk factors and audit programme modifications: Evidence from Jordan. Retrieved from https://www.researchgate.net/publication/274283415_Fraud_Risk_Factors_an d_Audit_Programme_Modifications_Evidence_from_Jordan on August 12, 2019.

Agyedu, G. O., Donkor, F. \& Obeng, S. (2011). Teach yourself research methods. Kumasi, Ghana: University of Education, Winneba.

Asemanyi, E. T. \& Wunko, V.D. (2007). The status of early childhood care and development in Aboadze- Aboadzi Township, Ghana. International Journal of Educational Research, 13(2), 234-248. August 08, 2019, from

Badders, W. (2000). Methods of Assessment. Retrieved on https://www.eduplace.com/science/profdev/articles/badders.html

Cobbold, C, (2011). Improving teaching and learning in the early childhood classroom in Ghana: Preparing teachers for developmentally appropriate practice. International Journal of Basic Education, 1(I), 1-8.

Cohen, J. (1969). Statistical power analysis for the behavioral sciences. San Diego, CA: Academic Press.

Dixon, F. A., Yssil, N., McConnell, J. M. and Hardin, T. (2014). Differentiated instruction, professional development and teacher efficacy. Journal for the education of the gifted. 37 (2), $111-127$.

French, G. (2007). The framework for early learning: A background paper. Children's early learning and development. Retrieved from 
https://arrow.dit.ie/cgi/viewcontent.cgi?article $=1006 \&$ context $=$ aaschssloth on August 12, 2019.

Funke K. O. (1992). Full time or part time a better way out; a case study of selected departments in university of Lagos (Unpublished Thesis University of Lagos).

Joppe, M. (2000). The research process. Retrieved from http://www.ryerson.ca/ mj oppe/rp.htm on February 24, 2015.

Ketabi, S. \& Ketabi, S. (2014). Classroom and Formative Assessment in Second/Foreign Language Teaching and Learning. Theory and Practice in Language Studies, 4, (2), pp. 435-440

Lankshear, C. \& Knobel, M. (2004). A handbook for teacher research. From design to implementation. New York, U S A: Open University Press.

Maheshwati, V. K. (2011). Sampling strategies for educational research. Roorkee, India: K.LD.A.V (P.G) College.

Natoli, C. (2011). The importance of audio-visual materials in teaching and learning. Retrieved from wwwhelium.com/channels224-earlychildhood-ed August 12, 2019.

Oku, K. (2008). Comparison of academic achievement of sandwich and regular post graduate student of University of Port Harcourt. (Unpublished M. Ed Thesis, University of Port Harcourt).

Okwara N. (1997). A comparative, study of academic achievements of the regular and post N.C.E sandwich students of the University of Port Harcourt (Unpublished Master Thesis, University of Port Harcourt).

Oliva, P.F. (1992). Developing the curriculum. (3 ${ }^{\text {rd }}$ ed.) New York. Harper Collins Publishers.

Owu-Ewie, C. (2006). The language policy of education in Ghana: A critical look at the English-only language policy of education. Retrieved from http://www.lingref.com/cpp/acal/35/paper1298.pdf on August 12, 2019.

Patton, M. Q. (2008). Utilization-focused evaluation (4 ${ }^{\text {th }}$ ed). Saint Paul (MN), Sage Publications.

Ruland, R. (2015). Understanding the experience of teachers in a professional learning community; A case study of an interdisciplinary ninth grade team. Retrieved https://pdfs.semanticscholar.org/90e4/1249341ae3d9ae1e19db2b0488948aa50 eb5.pdf on August 12, 2019.

Scriven, M. (1967). Perspective of curriculum evaluation, AERA. Monograph service on curriculum evaluation. No.1. Chicago. Rand Mc. Nally.

Stufflebeam, D. L. (2000). Checklists development checklist (www.wmich.edu/ evalctr/checklists/)

Tamakloe, E. T., Attah, E. T., Amedahe, F.K. (1996). Principles and methods of teaching, Accra. Black Mask Limited.

Tanner, D., \& Tanner, L. (1995). Curriculum development: Theory into practice. New Jersey: Prentice-Hall.

Tara, M. (2008). Summative and formative Assessment: Perceptions and realities. Retrieved on August 08, 2019, from https://www.researchgate.net/publication/258124505_Summative_and_Format ive_Assessment_Perceptions_and_Realities 
British Journal of Education

Vol.8, Issue 5, pp.1-14, May 2020

Published by $E C R T D-U K$

Print ISSN: ISSN 2054-6351: Online ISSN: ISSN 2054-636X

Tyler, R. (2013). Basic principles of curriculum and instruction. In: D. J. Flinders \& S. J. Thornton (Eds.), Curriculum Studies Reader (4th ed.), pp. 59-68. New York, NY: RoutledgeFalmer.

Velazquez, A. L. F. \& Assar, (2009). Student learning styles adaptation method based on teaching strategies and electronic media. Retrieved from https://www.researchgate.net/publication/220374113_Student_Learning_Style s_Adaptation_Method_Based_on_Teaching_Strategies_and_Electronic_Medi a on August 12, 2019.

Wheeler, D. K. (1967). Curriculum Process. London: Hodder and Stoughton.

Yakubu, J. M. (2000). Principles of curriculum design. Accra: Ghana University Press. 